\title{
DISTRIBUTION, DENSITY, AND BIOLOGICAL ASPECT OF Trichiurus lepturus IN THE SOUTHERN OF JAVA, INDIAN OCEAN EEZ OF INDONESIA
}

\author{
Fayakun Satria'), Wudianto'), and Awwaluddin ${ }^{2)}$ \\ 1) Research Center For Capture Fisheries, Ancol-Jakarta \\ 2) Research Institute for Marine Fisheries, Muara Baru-Jakarta \\ Received April 24-2006; Received in revised May 17-2006; Accepted June 23-2006
}

\begin{abstract}
Distribution, density, and biological aspect of Trichiurus lepturus in deeper parts of southern Jawa are described based on data obtained from research cruise in May 2005. The cruise has successfully made 52 stations of trawl across southern of Java. Trichiurus lepturus was found unevenly in the area but was particularly abundant on the flat sea bed in the depth ranges of 200 to $500 \mathrm{~m}$. Sex ratio was dominated by male $(60 \%)$ compared to female $(40 \%)$ with low breeding proportion index (0.18). Length and weight ranged from 69 to 112 $\mathrm{cm}$ and 130 to $755 \mathrm{~g}$ with $70 \%$ found in the stage of maturing. The main diet was mainly shrimps and myctophids.
\end{abstract}

KEYWORDS: Trichiurus lepturus, distribution, abundance, biological aspect

\section{INTRODUCTION}

Trichiurus lepturus has a wide distribution throughout Indonesia water as reported by Badrudin \& Wudianto (2004). This found in the estuarine waters until off marine waters. Trichiurus lepturus was reported to be fished by the local fishermen from the Java island from a relatively shallow to oceanic marine waters along the southern of Jawa waters (Badrudin \& Wudianto, 2004). The fishing season of this species was known all year around with a peak in the end of year to the early of the following year. Variety of fishing gears have been utilized by the fishermen to catch this silver shiny fish such as purse seine, gill net, set net, traps, and trawl. It was reported that not only the trend of stock abundance indeces but also the size of the fish was tend to decrease (Badrudin \& Wudianto, 2004).

In the field of systematic ichthyology Trichiurus lepturus was classified in the family of Trichiuridae. There were 10 genera in the family that is Diplospinus, Aphanopus, Benthodesmus, Lepidus, Epoxymetopon, Assurger, Tentoreiceps, Eupluerogrammus, Trichirurs, and Lepturacanthus (Badrudin \& Wudianto, 2004). To date there were three genera that commonly caught by fishermen in the Indonesian waters that is Eupluerogrammus, Trichiurus, and Lepturacanthus while their common species were Euplurogrammus muticus, Trichiurus lepturus, and Lepturacanthus savala.

Regarding the economic value Trichiurus lepturus has also well known as a marketable fish in the local market. The price were fluctuated ranging from Rp.2,000 to 10,000 per $\mathrm{kg}$. Today the catches were supplied to the local market as well as to other country.

During July to September 2005 for 107 days the cruise has successfully made 102 trawl stations. 52 trawl stations in southern of Jawa waters and 50 trawls stations in the western off Sumatera waters. There were no single Trichiurus lepturus has been found in the waters off Sumatera but quite densely distributed in Jawa waters. In this paper the distribution, density, and biological aspect of Trichiurus lepturus in the deep seas of southern of Jawa waters, Indian Ocean from the depth of 200 to $1,000 \mathrm{~m}$ will be described.

\section{MATERIALS AND METHODS}

The study area is extended between latitudes $6^{\circ} \mathrm{N}$ to $8.5^{\circ} \mathrm{S}$ and longitudes $106^{\circ} \mathrm{E}$ to $113^{\circ} \mathrm{E}$ off the South of Jawa water (Figure 1). 


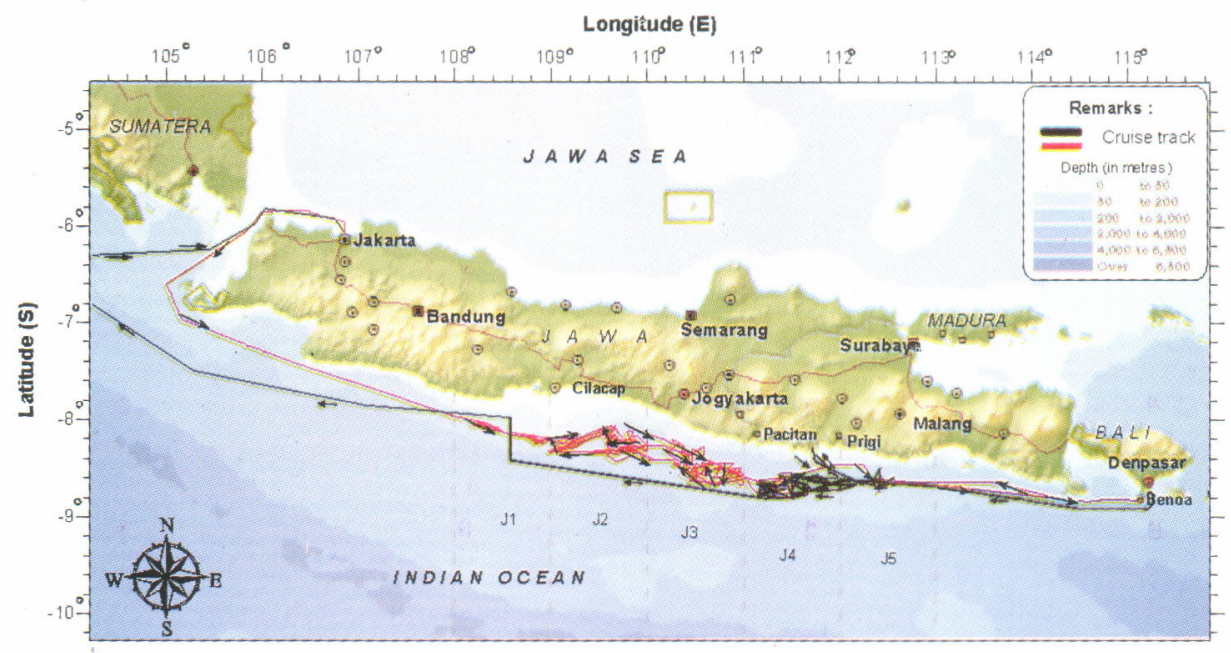

Figure 1. The cruise track during the survey.

\section{Sampling}

The data were obtained from research vessel Baruna Jaya IV cruises conducted during $2^{\text {nd }}$ of May 2005 to $3^{\text {rd }}$ of June 2005. The cruise was for demersal fish resources surveys while Trichiurus lepturus was taken into account as an observed species. Random stratified were applied in the cruise with samples ( $n=102$ stations) that taken from 3 depth strata from 200 to $1,100 \mathrm{~m}$ with increments between 200 to $500 \mathrm{~m}, 500$ to $750 \mathrm{~m}$, and 750 to $1,100 \mathrm{~m}$. Deep sea trawl used as a sample gear in the survey was described as head rope $=36 \mathrm{~m}$, ground rope $38 \mathrm{~m}$, head line height of 3.5 to $4 \mathrm{~m}$, wings tip spread of $24 \mathrm{~m}$, and was fished with a $40 \mathrm{~mm}$ liner in the cod end, and heavy rubber bobbin ground gear. The sampling strategy and trawl gears used on the cruise were described in detail by anonymous (2005). During the surveys catch data by numbers and weight, length compositions, and occasional stomach contents samples were available. The trawl positions obatained from GPS are shown in Figure 2.

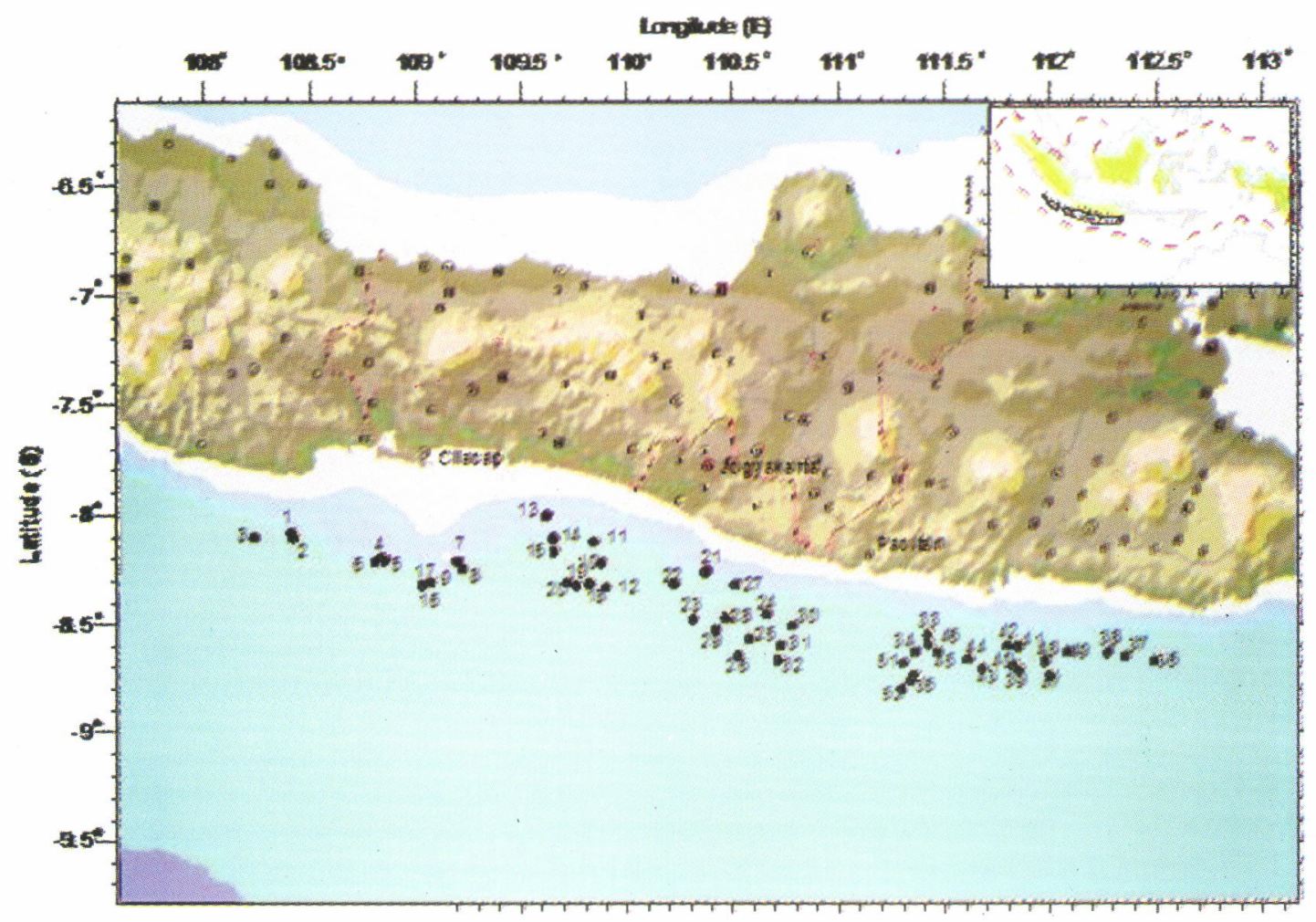

Figure 2. Positions of trawl operations in the southern of Jawa waters. 


\section{Biological Measurement}

From the catch of 22 stations there were 545 individuals of Trichiurus lepturus taken randomly and measured in length. 61 individuals were selected randomly in order to obtain detailed biological information i.e. length and weight, sex ratio, gonad weight, and stomach content. Photographs were taken for necessary information concerning for biological aspect of the species. Detailed data on individual specimens were collected, i.e. total length, sex, and stage of maturity, based on visual examination of gonads. The stages of maturity were classified into four stages with visual method i.e. mature (with globules and transparent of eggs on the gonad with bright in color), maturing (very few globules and white in color), immature (no globules, small in size, and weight), and spent (the gonad of membrane appear distract). Estimates of the coefficients $a$ and $b$ of the relationship $W(g)=a T L(c m)^{b}$ were obtained by power regression.

\section{Analyses of Distribution and Abundance}

Input to analyses of distribution and abundance was the weights and numbers of the individual catches in May 2005. The catches were adjusted to a standard 30 minutes tow. The catches were downed to the species and listed, tabulated, and recorded in the spread sheet for each station.

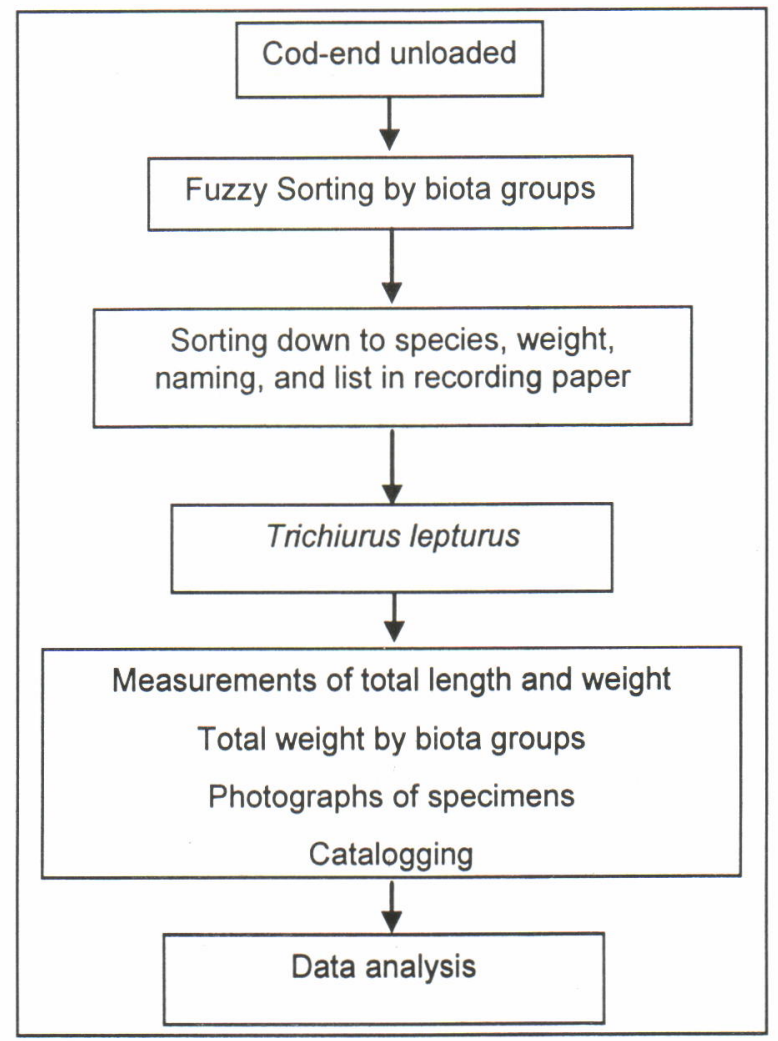

Figure 3. General procedure of data collection activity and their analysis.

Catch per unit effort and relative densities were obtained from swept area method. The models were based on the trawled area, speed, towing time, net opening, and the catches (Sparre \& Venema, 1992) i.e:

$$
\text { a.n=t.v.h.e.1,852.0.001 }
$$

where:

$$
\begin{aligned}
D & =(1 / a \cdot n) \cdot(c / f) \\
a \cdot n & =\text { the length of net track line }(k m)
\end{aligned}
$$

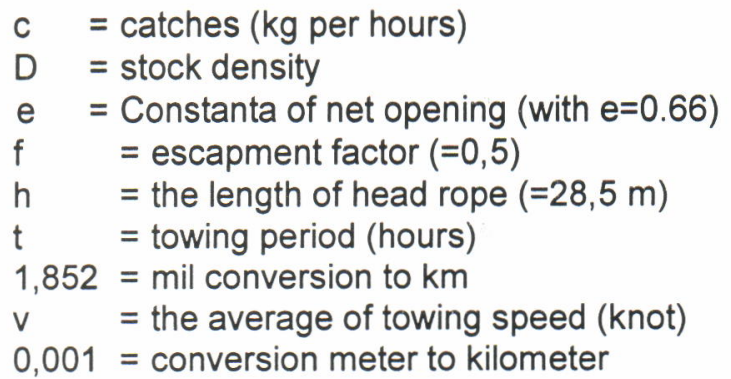




\section{RESULTS AND DISCUSSION}

\section{Distribution and Density}

Catches of Trichiurus lepturus occurred unevenly in the area sampled of southern Jawa Sea. Trichiurus lepturus was caught in 22 of a total of 52 trawls in the study area $(42.3 \%)$. There was a concentration of relatively big catches in the station no 001 and 020 for about 150 to $250 \mathrm{~kg}$ located between $108^{\circ} \mathrm{E}$ and $110^{\circ}$ E. In Figure 4, the catches from individual stations are plotted with symbol size proportional to the numbers in the catch. The populations are rarely found as shift to the West starting from $108^{\circ} \mathrm{E}$.

In term of vertical distribution the catches were higher in the depth from 200 to $500 \mathrm{~m}$ but very rare on the deeper than $500 \mathrm{~m}$ (Figure 5 and Table 1). The frequency of zero catches was higher in deeper depth strata $>500$ $\mathrm{m}$. The biggest catch (at $245 \mathrm{~m}$ ) contained 682 individuals. This suggested that Trichiurus lepturus has a limitation to inhabiting a deeper depth more than 500 $\mathrm{m}$. The limitation might be due to either physiology or habitat and food resources reason.

The distribution of Trichiurus lepturus seems limited to the area that attributes specific habitat. The habitat likely to inhabit was flat with soft substrate.

The estimation of stock density of Trichiurus lepturus was $350 \mathrm{~kg} \mathrm{~km}^{-2}$ with biomass occurred in the entire area that reached up to $3,860.4$ tonnes (Table 1).

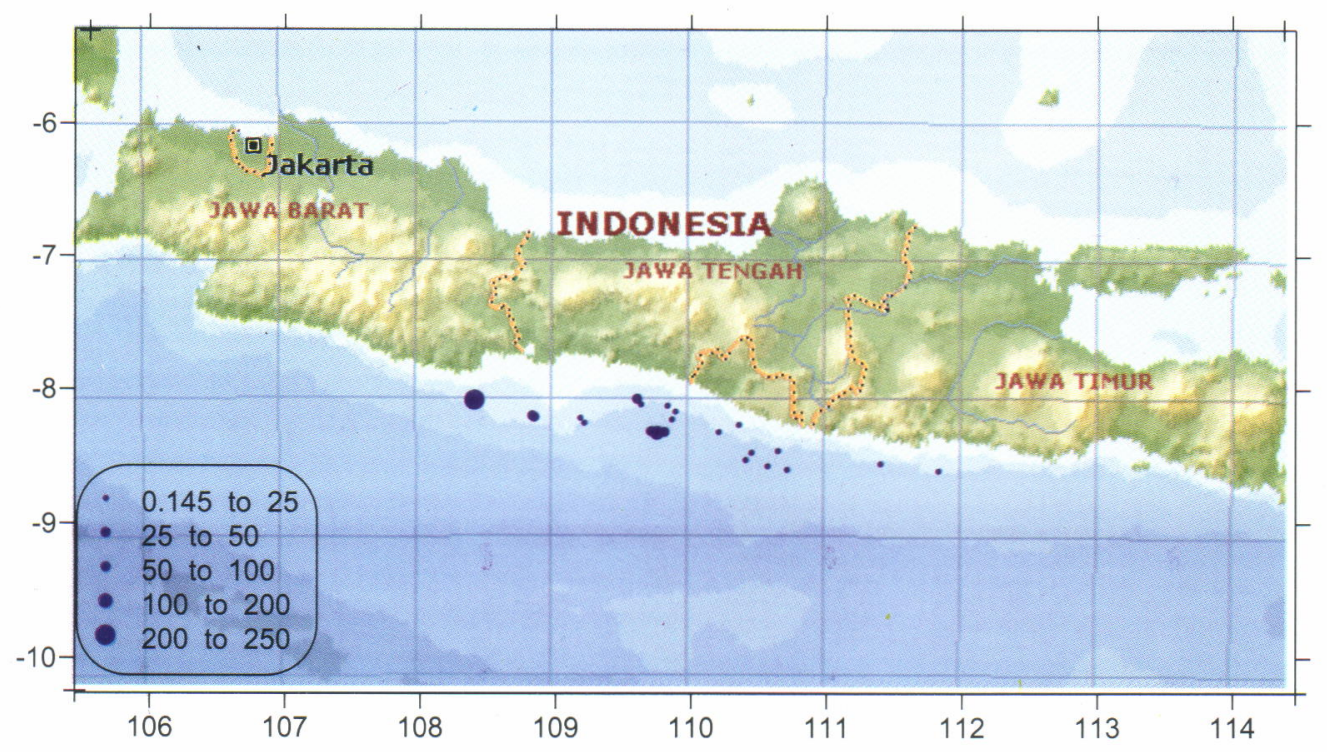

Figure 4. Horizontal distribution of Trichiurus lepturus.

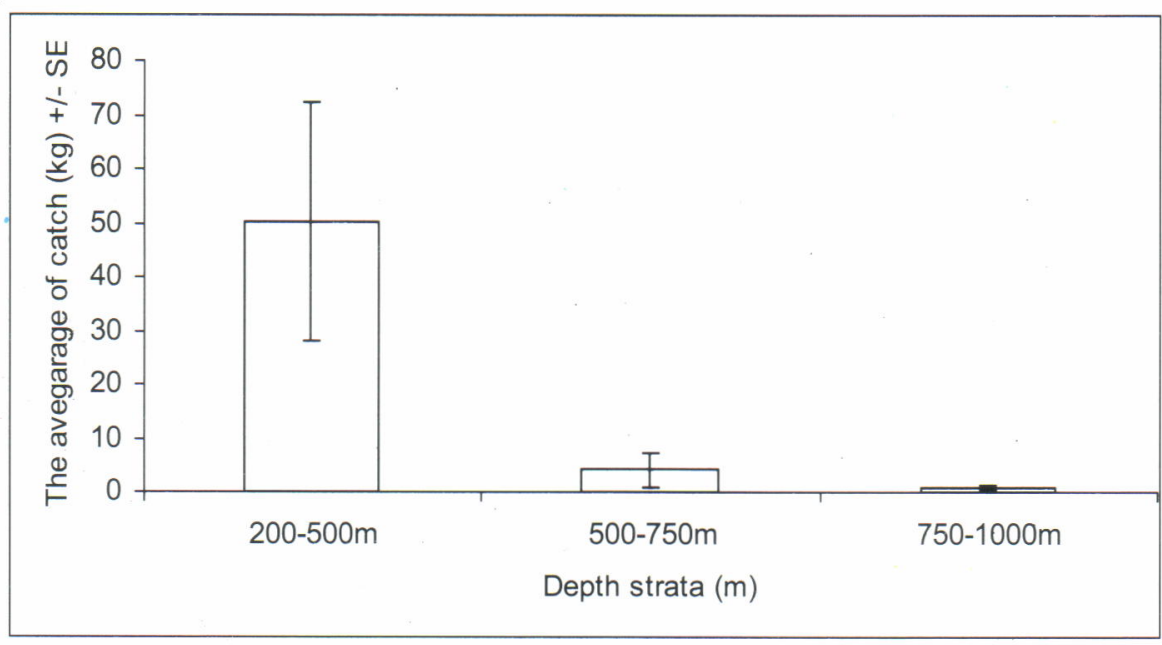

Figure 5. The average of catch on the basis of depth strata. 
Distribution, Density, and... in the Southem of Jawa, Indian Ocean Eez of Indonesia (Satria, F. et al.)

Table 1. Stock size of Trichiurus lepturus on the basis of depth strata in the surveyed area

\begin{tabular}{lcccc}
\hline \multicolumn{1}{c}{ Parameter } & $\mathbf{2 0 0 - 5 0 0 ~} \mathbf{~}$ & $\mathbf{5 0 0 - 7 5 0 ~}$ & $\mathbf{7 5 0 - 1 , 0 0 0 ~} \mathbf{~}$ & Total \\
\hline Total catch rate $(\mathrm{kg})$ & 545.12 & 2,395 & 1,415 & 546.53 \\
Average $(\mathrm{kg})$ & 10.48 & 0.05 & 0.03 & 10.51 \\
Swept area $\left(\mathrm{km}^{2}\right)$ & 0.06 & 0.06 & 0.06 & 0.06 \\
Stock Density $\left(\mathrm{kg} \mathrm{km}^{-2}\right)$ & 349.43 & 1.54 & 0.91 & 350.34 \\
Area $\left(\mathrm{km}^{2}\right)$ & 11,019 & 11,019 & 11,019 & 11,019 \\
Biomass (tonnes) & $3,850.40$ & 16.92 & 9.99 & $3,860.39$ \\
Fishing potency (tonnes per year) & $1,925.20$ & 8.46 & 5.00 & $1,930.20$ \\
\hline
\end{tabular}

Compared to the total catch $(4,295.5 \mathrm{~kg})$ Trichiurus lepturus was about $636.7 \mathrm{~kg}$. This revealed the species contributes a small quantity in the entire catches for $14.8 \%$ (Table 2).

\section{Biological Aspects of Trichiurus lepturus}

The size (TL) of Trichiurus lepturus ranged from 54 to $101 \mathrm{~cm}$ (Figure 6). The distribution of Trichiurus lepturus with respect to the depth and size revealed that the number of large Trichiurus lepturus were found in the depth stratum of 250 to 500 m while small Trichiurus lepturus were likely inhabit and found in deeper water column i.e. 500 to $1,000 \mathrm{~m}$. Fish size of $>88 \mathrm{~cm}$ tend to inhabit in the water column less than $500 \mathrm{~m}$ while smaller fish size i.e. 55 to $66 \mathrm{~cm}$ tend to inhabit at deeper water column 500 to $1,000 \mathrm{~m}$. If size related to the age this pattern might indicates that there is a shifting behaviour or physiology of the species when they reached a certain size and age.

Table 2. Comparison of the total catches of fish and Trichiurus lepturus with respect to the depth strata

\begin{tabular}{cccccc}
\hline $\begin{array}{c}\text { Depth range } \\
(\mathbf{m})\end{array}$ & $\begin{array}{c}\text { Number of } \\
\text { stations }\end{array}$ & $\begin{array}{c}\text { Average of } \\
\text { Trichiurus lepturus } \\
\text { catch rate } \mathbf{( k g )}\end{array}$ & $\begin{array}{c}\text { Average of fish } \\
\text { catch rate } \\
(\mathbf{k g})\end{array}$ & $\begin{array}{c}\text { Occurrence } \\
\text { percentage } \\
\text { by depth }\end{array}$ & $\begin{array}{c}\text { Percentage } \\
\text { by total catch } \\
\text { and depth }\end{array}$ \\
\hline $250-500$ & 12 & 50.24 & 292.3 & 91.3 & 17.2 \\
$500-750$ & 8 & 4.06 & 84.3 & 7.4 & 4.8 \\
$750-1,000$ & 2 & 0.70 & 57.0 & 1.3 & 1.2 \\
\hline Total & $\mathbf{2 2}$ & $\mathbf{5 5 . 0}$ & $\mathbf{4 3 3 . 5 6}$ & & \\
\hline
\end{tabular}

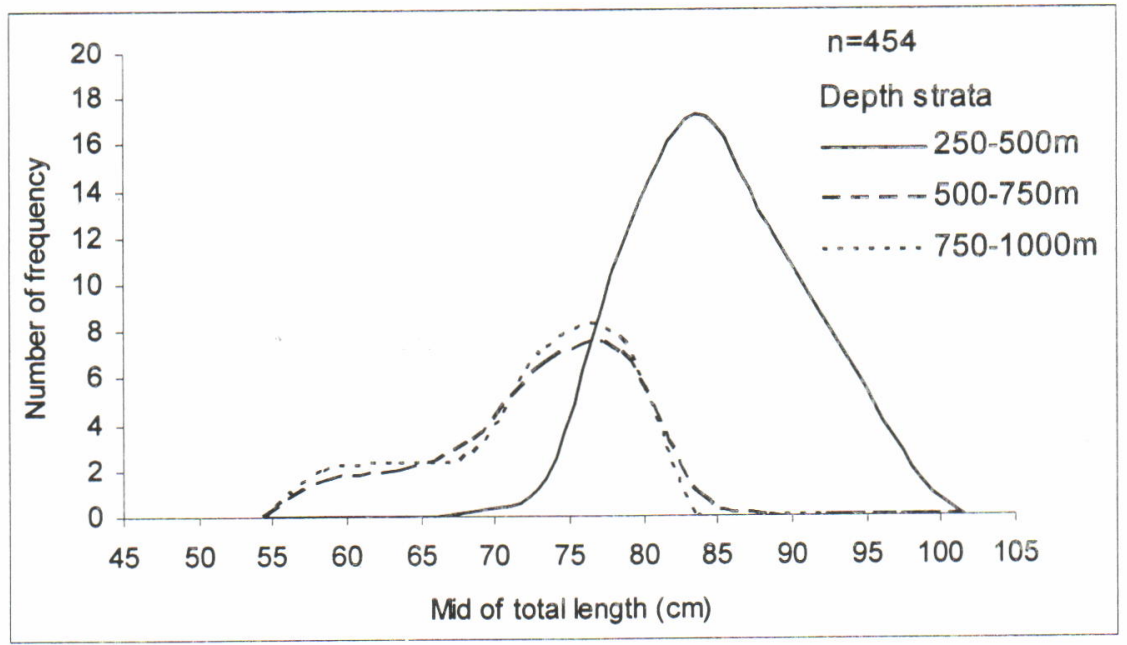

Figure 6. Size distribution of Trichiurus lepturus by depths. 
The length weight relationships $\mathrm{W}(\mathrm{g})=1 \mathrm{E}-04 \mathrm{TL}(\mathrm{cm})^{3.36}$ and $\mathrm{W}(\mathrm{g})=0.0003 \mathrm{TL}(\mathrm{cm})^{3.12}$ for female and male. The calculations were based on the measurements of $n=43$ females $\left(R^{2}=0.87\right)$ and $n=18$ males $\left(R^{2}=0.87\right)$ Trichiurus lepturus. The growth of Trichiurus lepturus was bigger than 3 , indicating to positive allometric growth type (Figure 7). The growth type confirmed that oceanic Trichiurus lepturus has a faster body weight growth compare to its length (Ingles \& Pauly, 1984) while coastal Trichiurus lepturus has been reported to have negative allometric growth type.

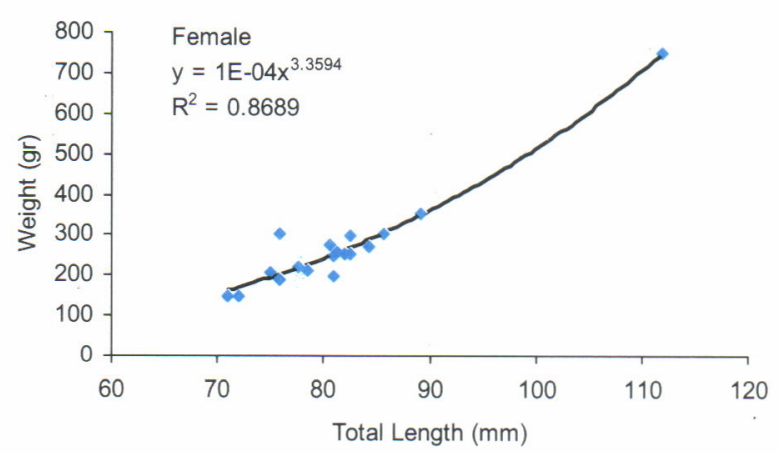

\section{Sex Ratio and Maturity}

Data on sex composition and sex ratio were recorded from 61 fish samples. There were 18 females $(29.5 \%)$ and 43 males (70.5\%) (Figure 8). Small proportion of females in a population indicates a high risk of harvesting the stock without an effective and carefully management.

The maturity stages of females were recorded for 18 females i.e. $27.8 \%$ mature, $72.2 \%$ maturing, no gonads were found in the stages of both immature and spent (Figure 9).

Figure 7. Length and weight relationships of Trichiurus lepturus.

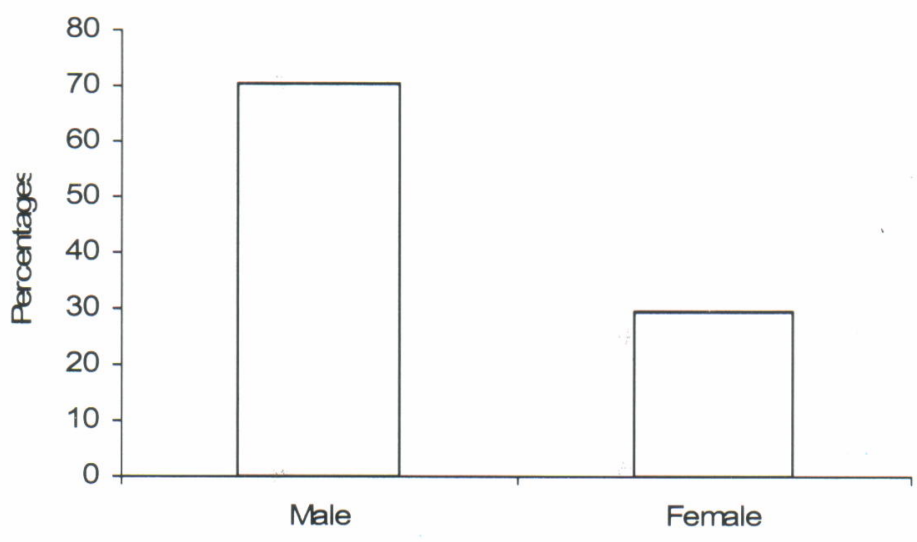

Figure 8. Sex ratio of Trichiurus lepturus. 


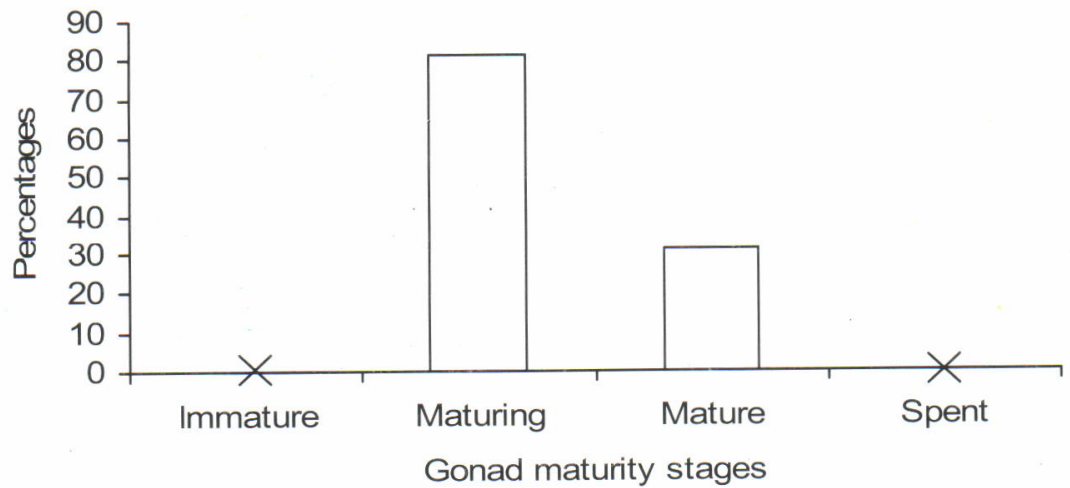

Figure 9. Sexual maturation of Trichiurus lepturus.

Average weight of maturing gonads was $9.4 \mathrm{~g}$ while mature $12.42 \mathrm{~g}$. There were 5 samples of gonad mature out of 28 samples giving a low breeding proportion index i.e. $0.18(\mathrm{BP}=\mathrm{TG} / \mathrm{MG})$. Average of gonado somatic indecs for female was $3.77 \%(1.2-7.1 \%)$ and male was $1.82 \%(0.5-3.7 \%)$.

\section{Diet}

A total of 40 stomachs were examined for food items. There were $55 \%$ (22) found filled and $45 \%$ (18) empty stomach. The most common food items were two prey categories that is shrimps and myctophids. Shrimps occurred in $60 \%$ of the stomachs, followed by small fishes (Myctophidae) 29\% and mix of fish and shrimps $11 \%$ (Figure 10). Sergestidae, Sergestes sp. was common species of the shrimps while Diaphus sp. myctophidae, was common species of the small fishes. This suggested that Trichiurus lepturus was a carnivore fish that mainly prey shrimps and Myctophids.

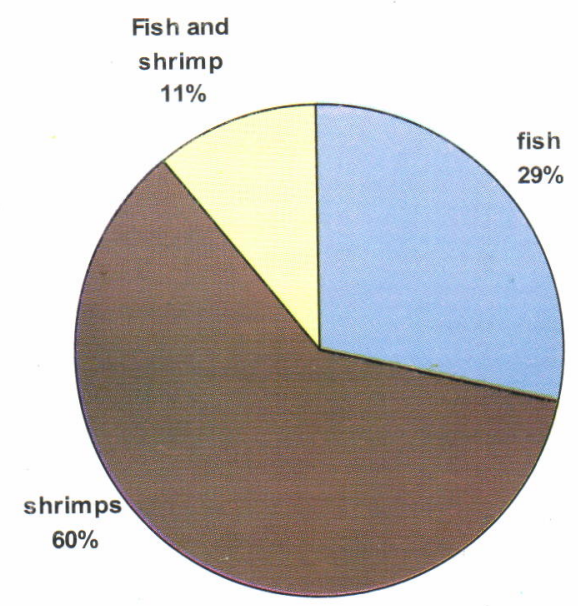

Figure 10. The main diet composition of Trichiurus lepturus. 


\section{CONCLUSION}

Trichiurus lepturus was unevenly distributed in the area and mostly concentrated on the flat sea bed area up to $500 \mathrm{~m}$ deep. Stock density of the population in average occurred for $350 \mathrm{~kg} \mathrm{~km}^{-2}$. The distribution of Trichiurus lepturus seems limited to the area that attributes specific habitat. The likely habitat to inhabit was flat with soft substrate. Trichiurus lepturus were more abundant in the area less than $500 \mathrm{~m}$. The population was dominated by male and giving low breeding proportion index 0.18 suggesting a vulnerable stock on fishing pressure. The growth was allometric positive informed a faster growth rate of body weight compare to the length. Trichiurus lepturus was a carnivore with the main prey of shrimps and mycthopids.

Acknowledgements:

This paper is part of 'Indonesian-Japan joint program on deep sea fisheries resources' in 2005.

\section{REFERENCES}

Anonymous. 2005. The Japan-Indonesia deep sea fishery resources joint exploration project (report of 2004 field survey). Overseas Fishery Foundation. Research Institute for Marine Fisheries.

Anonymous. 2006. The Japan-Indonesia deep sea fishery resources joint exploration project (report of 2005 field survey). Overseas Fishery Foundation. Research Institute for Marine Fisheries. $154 p+58$ app.

Badrudin \& Wudianto. 2004 Biologi, habitat, dan sebaran ikan layur serta beberapa aspek perikanannya. Co Fish Project. $13 \mathrm{p}$.

Ingles, J. \& Pauly. 1984. An atlas of the growth, mortality, and recruitment of Philippine fishes. ICLARM Tech. Report No.13. ICLARM. Manila. 127 p.

Sparre, P. \& S. C. Venema. 1992. Introduction to tropical fish stock assessment. Part 1. Manual. FAO Fish. Tech. Pap. No.306/1. Rev.1. 